\title{
Pengaruh Penerapan International Food Service Training Manila Terhadap Appraisal Koki di Perusahaan Pelayaran
}

\author{
Purnomo $^{1}$, April Gunawan Malau ${ }^{2}$ \\ 1, 2 Prodi Ketatalaksanaan Angkutan Laut dan Kepelabuhanan \\ Sekolah Tinggi Ilmu Pelayaran, Jakarta \\ Jl. Marunda Makmur No. 1 Cilincing, Jakarta Utara. Jakarta 14150
}

\begin{abstract}
Abstrak
Sumber daya pelaut yang berkualitas sangat diperlukan perusahaan pelayaran dalam menghadapi era globalisasi yang ditandai dengan kemajuan dibidang teknologi transportasi laut dan perkapalan. Penelitian ini mengkaji tentang sejauh mana pengaruh penerapan IFS Training terhadap appraisal koki di perusahaan pelayaran sebelum dan sesudah mengikuti training, kemudian sejauh mana hubungan penerapan IFS Training menunjukan peningkatan hasil yang signifikan terhadap evaluasi kinerja dan laporan performace koki di atas kapal melalui laporan appraisal. Metode penelitian yang digunakan adalah kuantitatif, dengan teknik analisis data analisis korelasi, analisis determinasi dan analisis regresi linier sederhana. Dari hasil penelitian diperoleh kesimpulan bahwa bahwa penerapan IFS Training memiliki hubungan dan pengaruh yang signifikan terhadap appraisal koki. Jadi dari hasil analisis statistik diperoleh terdapat pengaruh dan hubungan yang signifikan dari penerapan IFS Training terhadap appraisal koki di perusahaan pelayaran setelah mengikuti IFS Training dan kembali bekerja di atas kapal.
\end{abstract}

Copyright $($ ) 2020, Prosiding Seminar Pelayaran dan Riset Terapan

Kata Kunci: pengaruh, food service, koki

Permalink/DOI : https://doi.org/10.36101/pcsa.v2i1.129

\section{PENDAHULAN}

Perdagangan internasional yang kian berkembang saat ini, menjadi pemicu sibuknya ekspor dan impor barang antar negara, khususnya dibidang industri pelayaran niaga. Industri pelayaran niaga dengan kegiatan utamanya pengiriman barang baik dalam negeri maupun antar negara dengan menggunakan moda transportasi laut yang berkembang semakin pesat menuntut setiap perusahaan pelayaran meningkatkan kualitas pelayanannya. Berbagai strategi dilakukan perusahaan pelayaran untuk bersaing mendapatkan muatan untuk diangkut demi kelangsungnya operasi kapal yang akan mendatangkan keuntungan bagi perusahaan. Salah satu strategi tersebut adalah pemilihan pelaut yang berkualitas yang akan dipekerjakan di atas kapal milik perusahaan.

Dalam usaha mengembangkan suatu perusahaan pelayaran, sumber daya manusia merupakan salah satu faktor yang sangat penting dan harus diperhatikan, karena pelaut merupakan operator yang menjalankan seluruh kegiatan operasional kapal yang dimiliki perusahaan pelayaran. Modal perusahaan yang besar serta fasilitas kapal yang canggih harus ditunjang oleh sumber daya pelaut yang memiliki kompetensi untuk menjamin kelancaran aktivitas pengiriman muatan.

Sumber daya pelaut yang berkualitas sangat diperlukan perusahaan pelayaran dalam menghadapi era globalisasi yang ditandai dengan kemajuan dibidang teknologi transportasi laut dan perkapalan. Pelaut yang mampu beradaptasi dan memiliki kompetensi menjalankan teknologi canggih diperlukan perusahaan pelayaran dalam mencapai kemajuan untuk bersaing dalam industri pelayaran. Sumber daya pelaut yang memiliki kompetensi tidak hanya pandai, tetapi juga memenuhi semua syarat kualitas standar yang ditentukan perusahaan yang memperkerjakan pelaut tersebut, sehingga pekerjaan yang dibebankan dapat diselesaikan sesuai harapan perusahaan.

Syarat - syarat kualitas standar yang harus dipenuhi antara lain adalah pengetahuan, keterampilan, kemampuan, kepribadian, sikap, dan perilaku. Keuntungan yang didapat oleh perusahaan pelayaran tidak lepas dari pelaut yang berperan penting untuk eksistensi perusahaan, maupun keberadaan pelaut itu sendiri. Salah satu faktor yang menunjang kesejahteraan pelaut 
disuatu perusahaan adalah performance atau kinerja yang menentukan kelayakan pelaut tersebut masih layak dipekerjakan atau tidak. Setiap pelaut diatas kapal tentunya memiliki tanggung jawab dimasing - masing department.

Terdapat tiga department yang ada di atas kapal yang beroperasi di bidang perkapalan niaga di perusahaan Anthony Veder Shipping Management Jakarta. Ketiga deparment tersebut, yaitu deck department, engine department, dan catering department. Tiap department mempunyai penanggung jawab yang memiliki keahlian dibidangnya masing - masing. Mulai dari captain sebagai posisi teratas, officer, engineer, dan rating. Masing - masing dari mereka memiliki tanggung jawab besar demi kelangsungan keamanan dan keselamatan di atas kapal, agar tanggung jawab itu dapat berjalan dengan baik tentunya hal tersebut bergantung pada performance atau kinerja yang baik pula dan salah satu faktor penunjang performance atau kinerja yang mereka berikan bergantung pada asupan makanan yang mereka terima.

Tidak hanya itu seorang koki harus mempunyai keterampilan dan kemampuan bagaimana cara ia memberikan hidangan yang dapat diterima oleh semua awak kapal, karena hal ini pula mempengaruhi produktivitas semua awak kapal dalam bekerja. Permasalahan yang terjadi saat ini adalah terdapat masalah khususnya dari catering department di kapal - kapal yang beroperasi milik Perusahaan Anthony Veder. Catering departement memiliki peran penting dalam struktur organisasi kapal sebagai operational support bagi kedua department lainya. Masalah yang terjadi adalah yang pertama ketidakmampuan skill dan kurangnya kompentensi atau pengetahuan koki, tidak hanya membuat dampak yang besar bagi awak kapal namun juga perusahaan Anthony Veder.

Pertama, kemampuan mengolah makanan yang tidak variatif dan kurang baik sehingga menyebabkan hasil dari masakan yang tidak dapat diterima oleh awak kapal. Kedua, ketidakmampuan koki untuk mengatur, mengendalikan, dan menggunakan persediaan bahan makanan (storing). Seperti menyimpan persediaan bahan makanan dalam keadaan suhu yang tidak sesuai. Sehingga menyebabkan bahan makanan dalam store membusuk sebelum batas waktu yang telah ditentukan dan diperkirakan.

Hal ini berkaitan dengan biaya yang sudah dianggarkan oleh perusahaan Anthony Veder, karena persediaan bahan makanan yang busuk menyebabkan borosnya penggunaan bahan makanan serta berkaitan pula pada borosnya pengeluaran saat pembelanjaan bahan makanan untuk provision. Ketiga, kurangnya kepedulian dan perhatian koki terhadap kebersihan alat - alat untuk mengolah makanan dan lingkungannya. Seperti penggunaan pemanas makanan atau microwave di dapur dibiarkan berkarat dan meninggalkan plak pada dinding microwave. Hal ini berkaitan dengan keamanan lingkungan di dapur karena, berkaratnya microwave merupakan suatu nearmiss atau potensi dari rusaknya microwave, yang berakibat terbakarnya microwave yang membahayakan keselamatan dan keamanan jiwa seluruh crew di atas kapal.

Terdapatnya masalah koki yang terjadi diatas kapal yang berkenaan dengan skill dan performance berdampak kurangnya hasil appraisal atau evaluasi kinerja per 3 bulan yang di kirim langsung dari captain kepada training and supporting department Jakarta, hal ini menjadi pemikiran bagaimana menanggapi dan solusi dari masalah tersebut, khususnya untuk koki berkewarganegaraan Indonesia yang manajemennya di bawah Anthony Veder Shipping Management Jakarta. Adanya masalah yang berkaitan dengan peran koki yang terjadi di atas kapal milik perusahaan Anthony Veder, memolopori Officer Conference September 2014 Rotterdam yang diadakan oleh Anthony Veder Rederijzaken Rotterdam. Officer Conference September 2014 Rotterdam adalah konferensi yang membahas masalah catering department khususnya yang terjadi di kapal - kapal milik Anthony Veder yang bertujuan untuk memperbaiki kualitas standar diatas kapal di bidang catering department dengan mengimplementasi pelatihan International Food Service Training bagi koki yang bekerja di atas kapal. Selain itu pelatihan ini diharapkan dapat memberi bekal dan modal guna membantu koki serta meningkatkan performance atau kinerja mereka pada saat melakukan pekerjaannya diatas kapal.

Perusahaan Anthony Veder Shipping Management Jakarta merupakan salah satu perusahaan pelayaran yang bergerak dibidang crewing atau pengawakan kapal yang merupakan cabang perusahaan Anthony Veder Rederijzaken Rotterdam. Karena hampir seluruh koki yang bekerja di kapal milik Anthony Veder berkewarganegaraan Indonesia, maka Anthony Veder Shipping Management Jakarta bertugas untung mengatur dan mengurus koki yang sign on dan sign off untuk mengikuti IFS Training di Manila, Filipina. yang melakukan langkah nyata untuk meningkatkan performance atau kinerja koki yang bekerja di kapal milik Anthony Veder sendiri dengan mengharuskan dan mewajibkan semua koki berkewarnegaraan Indonesia yang bekerja di kapal Anthony Veder untuk diikutsertakan dalam 
International Food Service Training di Manila pada tahun $2014-2015$.

Alasan mengapa IFS Training di Manila sangatlah perlu dilakukan, karena hal ini berkaitan dengan masalah yang terjadi di atas kapal Anthony Veder mengenai adanya pengetahuan mengenai mengolah makanan yang tepat untuk asupan awak kapal, kebersihan dalam memasak serta penyimpanan makanan, manajemen persediaan makanan di food storage yang berhubungan dengan provision dan budget. Harapannya keikutsertaan beberapa koki pada IFS Training 2014 / 2015 dapat meningkatkan skill dan performance diatas kapal, yang ukurannya dapat dilihat pada appraisal yang evaluasinya didapat dari captain per 3 bulan. Namun apakah IFS Training yang telah dilakukan berpengaruh baik terhadap evaluasi kinerja yang dinilai melalui appraisal di atas kapal bagi koki itu sendiri

Berdasarkan hal tersebut peneliti menguraikan identifikasi masalah, yaitu:

1. Kurangnya kemampuan koki untuk mengolah makanan dengan baik, ketidakmampuan koki untuk mengatur, mengendalikan, dan menggunakan persediaan bahan makanan (storing), dan kurangnya kepedulian serta perhatian koki terhadap kebersihan.

2. Menurunnya hasil appraisal atau evaluasi kinerja pertiga bulan yang berkaitan langsung dengan karir dan keberadaan koki itu sendiri untuk kelangsungan kontraknya dengan Anthony Veder.

Berdasarkan uraian yang telah disampaikan dalam latar belakang, peneliti merumuskan permasalahan sebagai berikut:

1. Sejauh mana pengaruh penerapan IFS Training terhadap appraisal koki di PT. Antony Veder Shipping Management Jakarta sebelum dan sesudah mengikuti training ?

2. Sejauh mana hubungan penerapan IFS Training menunjukan peningkatan hasil yang signifikan terhadap evaluasi kinerja dan laporan performace koki di atas kapal melalui laporan appraisal?

Kemudian tujuan dilaksanakannya penelitian ini yaitu:

1. Untuk mengetahui sejauh mana pengaruh penerapan IFS Training terhadap appraisal koki di PT. Anthony Veder Shipping Management Jakarta.

2. Untuk mengetahui sejauh mana hubungan IFS Training menunjukan peningkatan hasil yang signifikan terhadap evaluasi kinerja dan laporan performance koki di atas kapal melalui appraisal.
Metode Pendekatan yang digunakan dalam penelitian ini adalah kuantitatif. Penelitian bertempat di Jakarta tepatnya di Kantor perwakilan Anthony Veder untuk Indonesia. Alamat kantor Anthony Veder Jakarta. Adapun populasi dari penelitian ini adalah jumlah seluruh koki yang bekerja di Anthony Veder sejumlah 42 orang. Sedangkan sampel dari penelitian ini adalah koki yang sudah dijadwalkan dalam keikutsertaannya untuk mengikuti IFS Training sejumlah 26 orang. Pengambilan data dilakukan dengan observasi, dokumentasi dan wawancara.

Teknik yang digunakan oleh peneliti adalah analisis korelasi, analisis determinasi dan analisis regresi linier sederhana. Teknik ini digunakan untuk membuktikan analisa hubungan antara data jumlah hasil appraisal sebelum (Variabel Y) dan data jumlah hasil appraisal setelah mengikuti IFS Training (Variabel X) yang dampaknya pada kesesuaian gambaran kinerja maupun perfomance koki saaat bekerja diatas kapal. Analisis yang dilakukan adalah dengan menggunakan hasil rata rata nilai appraisal dari dua variabel, yaitu variabel $X$ (data jumlah hasil setelah mengikuti IFS Training) dan variabel $Y$ (data jumlah hasil sebelum mengikuti IFS Training).

\section{HASIL DAN PEMBAHASAN}

Data hasil observasi ini merupakan hasil laporan dari Presentasi Officer Conference September 2014 di Rotterdam, Belanda. Data tersebut berupa gambar dan kondisi yang terjadi di atas kapal khususnya di catering department.

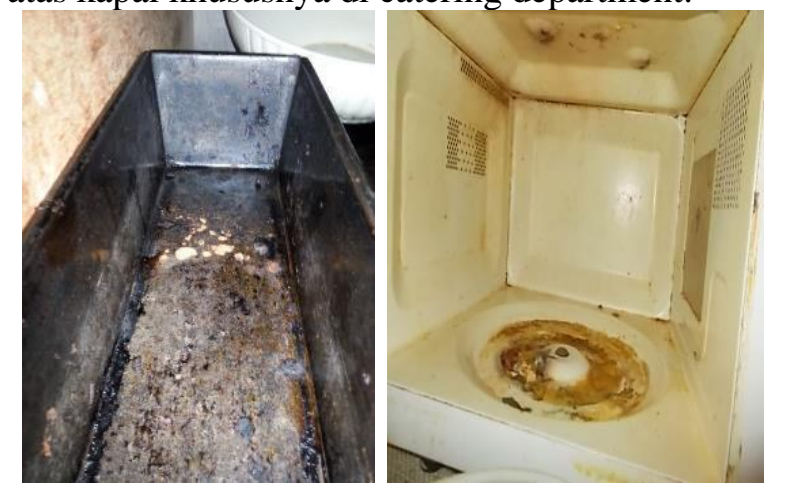

Gambar 1. Pengaratan pada bagian alat untuk proses produksi makanan

Terjadinya pengaratan pada dinding alat memasak yang membahayakan kualitas produksi dari makanan dan resiko pada keamanan di Galley

\section{METODE}




\section{http://ejournal.stipjakarta.ac.id/index.php/pcsa}

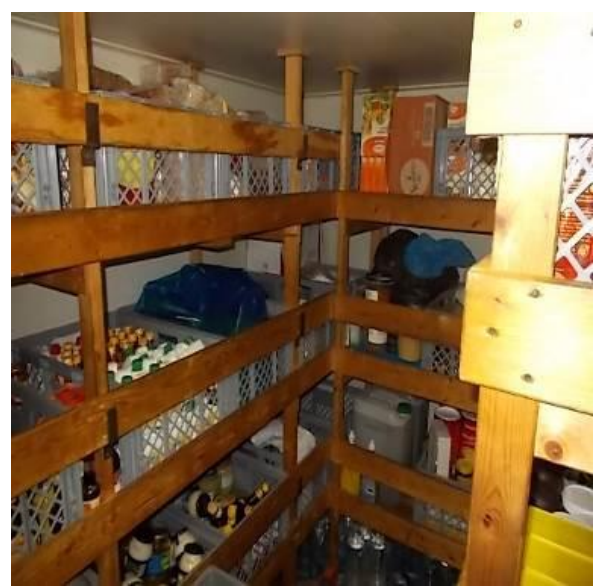

Gambar 2. Tidak teraturnya penempatan bahan makanan

Pengaturan manajemen bahan makanan / storing yang tidak teratur dipenyimpanan beresiko terhadap ketahanan bahan makanan, karena perbedaan ketahanan bahan makanan yang berbeda - beda.

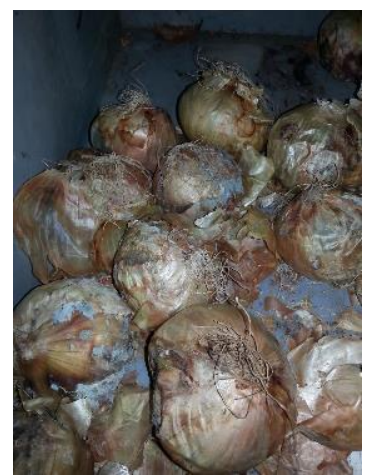

Gambar 3. Contoh Bahan makanan yang berjamur

Terdapat sisa bahan makanan yang terbuang karena berjamur, hal ini menandakan manajemen penggunaan bahan makanan yang tidak baik yang berakibat kerugian perusahaan pada saat provision nantinya.

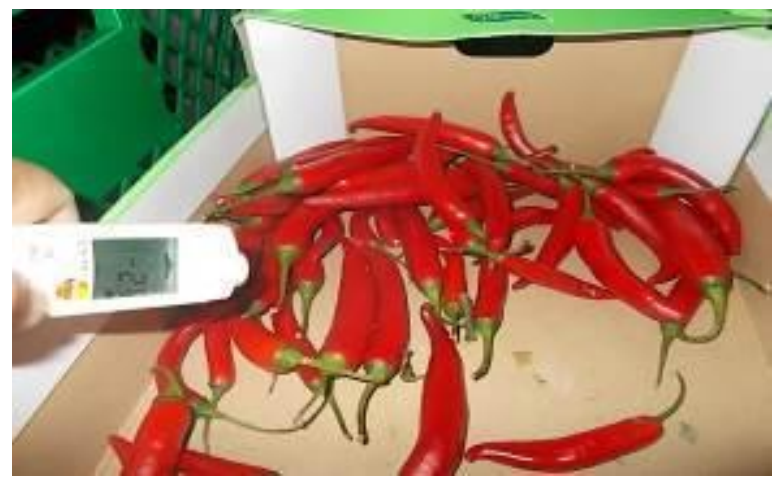

Gambar 4. Ketidaksesuaian suhu pada peletakan makanan

Ketidaksesuaian suhu pada peletakan makanan dapat berakibat kecenderungan cepatnya bahan makanan terinfeksi bakteri / resiko cepatnya bahan makanan untuk membusuk.
Tabel 1. Tabel Hasil Appraisal Koki Setelah dan Sebelum Mengikuti IFS Training

\begin{tabular}{|c|c|c|}
\hline \multirow{2}{*}{ Responden } & \multicolumn{2}{|c|}{ Average Appraisal Score } \\
\cline { 2 - 3 } & $\mathbf{X}$ & Y \\
\hline 1 & 7 & 6,6 \\
\hline 2 & 6,4 & 6,1 \\
\hline 3 & 7 & 6,6 \\
\hline 4 & 8 & 6.3 \\
\hline 5 & 6,9 & 5,9 \\
\hline 6 & 7,6 & 6,9 \\
\hline 7 & 7,1 & 6,6 \\
\hline 8 & 7,4 & 6,5 \\
\hline 9 & 6,8 & 6 \\
\hline 10 & 6,8 & 6,2 \\
\hline 11 & 7,1 & 6 \\
\hline 12 & 7,2 & 6,3 \\
\hline 13 & 7 & 6,7 \\
\hline 14 & 7,3 & 6,3 \\
\hline 15 & 8 & 7 \\
\hline 16 & 8,2 & 7,6 \\
\hline 17 & 7,4 & 6,5 \\
\hline 18 & 7 & 5,6 \\
\hline 19 & 6,5 & 5,4 \\
\hline 20 & 7,5 & 6,5 \\
\hline 21 & 7,7 & 6,8 \\
\hline 22 & 6.6 & 5,2 \\
\hline 23 & 7,6 & 6 \\
\hline 24 & 7,6 & 6,6 \\
\hline 25 & 7,2 & 5,5 \\
\hline 26 & 8 & 6,9 \\
\hline
\end{tabular}

$\mathrm{X}$ : Hasil rata - rata nilai appraisal sesudah mengikuti IFS Training Manila

Y : Hasil rata - rata nilai appraisal sebelum mengikuti IFS Training Manila

Hasil observasi pemeriksaan dilakukan pada salah satu kapal yaitu Coral Pavona pada tanggal 8 November 2015. Data di bawah ini menggambarkan kondisi setelah IFS Training Manila.

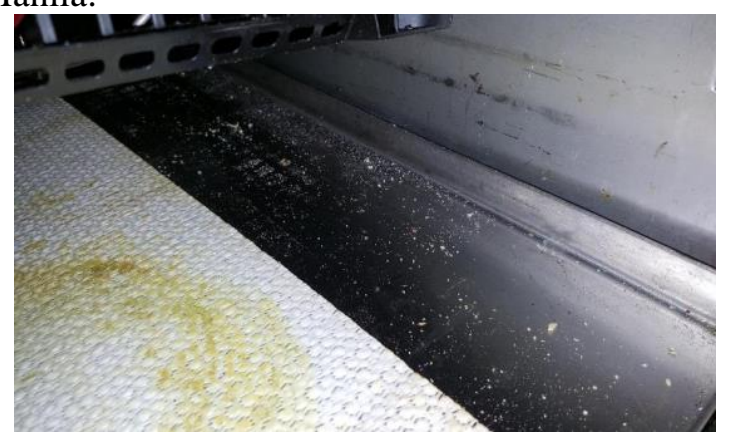

Gambar 5. Debu dalam sudut lemari dan tempat penyimpanan 
Kondisi dari luar lemari yang sudah cukup bersih, namun masih perlu dilakukan pembersihan hingga kesudut - sudut penyimpanan.

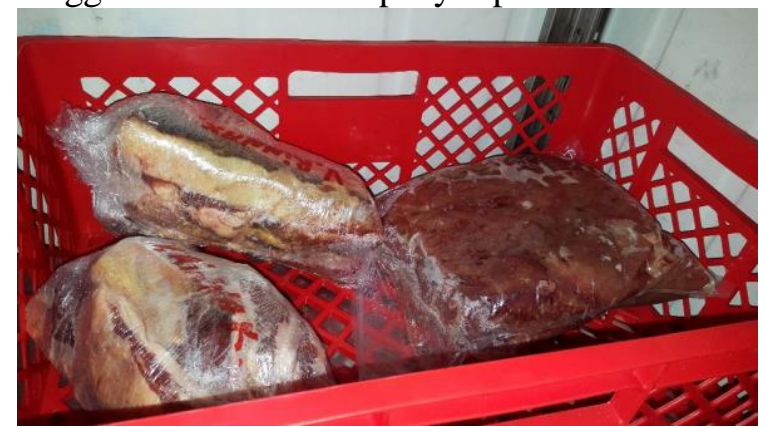

Gambar 6. Penempatan dan pemberian label

Tidak semua bahan makanan berdaging diletakan di dalam kulkas dan penanganannya sudah diberikan label expiry date untuk mencegah pembuangan karena kelalaian dalam mengetahui batas pemakaian.

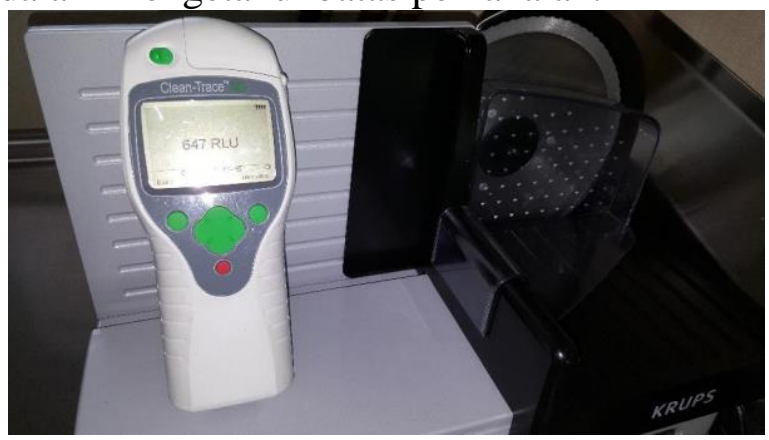

Gambar 7. Alat tes untuk memeriksa bakteri

Di mesin pengiris atau pemotong terukur dibawah terukur 647 RLU (Seharusnya bisa dibawah 200 RLU dapat menjadi lebih baik).

Kedua variabel ini sebagai pembukti bahwa adanya hubungan pengaruh penerapan IFS Training sebelum dan sesudah mengikuti training tersebut yang berdampak kepada kesesuaian koki bekerja di atas kapal. Dua variabel tersebut dapat dilihat dalam tabel IV.2 yaitu data total hasil nilai rata - rata appraisal setelah mengikuti IFS Training dan sebelum mengikuti IFS Training dalam periode Januari 2014 - Desember 2015.

$\mathrm{X}$ : Variabel bebas (independent variable) adalah rata - rata hasil appraisal di atas kapal setelah mengikuti IFS Training.

Y : Variabel tidak bebas (dependent variable) / variabel terikat adalah rata - rata hasil appraisal di atas kapal sebelum mengikuti IFS Training

Adanya kedua variabel yang akan dikorelasikan menggunakan rumus statistik, menunjukan variabel $\mathrm{X}$ merupakan rata - rata hasil appraisal di atas kapal setelah mengikuti IFS Training memiliki perbedaan dengan variabel Y yang menunjukan rata - rata hasil appraisal di atas kapal sebelum mengikuti IFS Training. Sebelumnya peneliti memiliki hipotesis bahwa perubahan nilai rata - rata pada variabel $\mathrm{X}$ mampu berubah dari variabel $\mathrm{Y}$ yang menandakan bahwa adanya pengaruh IFS Training terhadap cook / juru masak. Variabel $\mathrm{Y}$ sebagai variabel terikat yaitu sebelum mengikuti IFS Training, dapat menunjukan bahwa IFS Training dapat mempengaruhi variabel $\mathrm{Y}$ dengan melihat variabel $\mathrm{X}$ yaitu nilai rata - rata appraisal setelah mengikuti IFS Training serta membuktikan bahwa adanya korelasi antara variabel $\mathrm{X}$ (variabel bebas / independen) dengan variabel $\mathrm{Y}$ (variabel terikat / dependen).

Kemudian untuk rata - rata hasil appraisal sebelum mengikuti IFS Training, peneliti menggunakan appraisal dari periode Januari 2014 sampai jadwal sebelum koki mengikuti IFS Training. Setelah mengikuti IFS Training sesuai jadwal, koki kembali bekerja ke atas kapal sesuai planning dari Crewing Department. Kemudian peneliti mengambil kembali hasil appraisal setelah koki kembali bekerja di atas kapal yang hasilnya didapat dari email kapten sampai periode Desember 2015, lalu peneliti kembali membuat rata - rata hasil appraisal setelah mengikuti IFS Training. Dari tabel tersebut tertera jumlah average appraisal score yang peneliti buat dalam periode Januari 2014 - Desember 2015 adalah jumlah average appraisal score sesudah mengikuti IFS Training sejumlah 182,3 dan jumlah average appraisal score sebelum mengikuti IFS Training sejumlah 158,3.

Dari hasil observasi peneliti mengambil kesimpulan bahwa jumlah average appraisal score setelah mengikuti IFS Training lebih besar dibandingkan dengan average appraisal score sebelum mengikuti IFS Training.

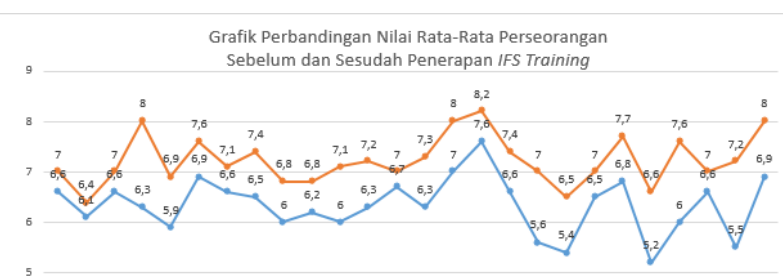

Gambar 8. Grafik perbandingan nilai rata - rata appraisal cook sebelum dan sesudah mengikuti IFS Training Manila 
Selanjutnya dilakukan analisis koefisien korelasi untuk mengetahui kuat atau tidaknya pengaruh variabel $\mathrm{X}$ terhadap variabel $\mathrm{Y}$.

Dari hasil perhitungan diperoleh koefisien korelasi sebesar 0.97. Hal ini mengindikasikan bahwa variabel $\mathrm{X}$ memiliki korelasi yang erat terhadap variabel $\mathrm{Y}$. Hal ini dibuktikan dengan semakin dekatnya nilai $r$ terhadap angka 1 ( satu ) maka hubungan kedua variabel semakin erat.

Untuk dapat mengetahui besarnya pengaruh IFS Training Manila dapat dihitung dengan menggunakan koefisien determinasi. Dari hasil perhitungan diperoleh koefisien determinasi sebesar $94 \%$, yang berarti kontribusi variabel $X$ terhadap variabel Y adalah sebesar 94\%.

Model regresi linear yang diperoleh adalah $\hat{\mathrm{Y}}=-258,34+0.90 \mathrm{X}$

Nilai 0.90 ini berarti apabila variabel $X$ (hasil appraisal penerapan IFS Training) naik 1, akan berdampak terhadap peningkatan kinerja/performance cook di atas kapal seperti yang di lihat perbedaan variabel $Y$ (hasil appraisal sebelum mengikuti IFS Training). Disimpulkan bahwa penerapan IFS Training mempengaruhi laporan hasil appraisal, yang mendeskripsikan kinerja / performance juru masak di atas kapal.

Alternatif pemecahan masalah merupakan suatu solusi yang dapat digunakan untuk memecahkan masalah. Dalam beberapa hal, pihak yang terkait dalam masalah ini mungkin dapat juga melakukan uji coba dengan pemecahan masalah yang terbaik dengan mencoba satu alternatif mana yang paling efektif. Pada umumnya pengambilan keputusan akan menggunakan pengetahuan, pertimbangan, dan pengalaman untuk memutuskan alternatif mana yang paling baik digunakan untuk memecahkan masalah. Berikut 2 masalah yang akan diberikan alternatif pemecahannya oleh peneliti :

1. Kurangnya kemampuan koki untuk mengolah makanan dengan baik, ketidakmampuan koki untuk mengatur, mengendalikan, dan menggunakan persediaan bahan makanan (storing), dan kurangnya kepedulian serta perhatian koki terhadap kebersihan.

2. Menurunnya hasil appraisal atau evaluasi kinerja pertiga bulan yang berkaitan langsung dengan karir dan keberadaan koki itu sendiri untuk kelangsungan kontraknya dengan Anthony Veder.

Kemudian peneliti memberikan beberapa alternatif pemecahan masalah yang akan diterapkan antara lain :

a. Menetapkan IFS Training sebagai standar training yang harus di ikuti cook / juru masak berikutnya.

b. Merekrut crew yang berkualitas.
Membuka penerimaan crew yang sesuai kebutuhan kualifikasi, dengan kata lain membuka kesempatan yang besar bagi para pelaut yang berposisi sebagai juru masak untuk melamar di Anthony Veder Jakarta.

c. Test penyeleksian crew recruitment lebih ditingkatkan.

Test penyeleksian crew recruitment lebih ditingkatkan. Dalam hal ini karyawan recruitment and Selection Department meningkatkan test penyeleksian untuk penerimaan crew baru seperti halnya test tertulis (psikotest, bahasa inggris, pengalaman), dan test wawancara dengan menggunakan bahasa inggris.

d. Meningkatkan kualifikasi crew yang sudah ada. Strategi ini dapat diterapkan dengan memberikan pelatihan kepada crew sebelum sign on (training pre-joining) dengan mengadakan In House Training sebagai pelatihan kemampuan, diluar kemampuan dasarnya sebagai cook.

e. Pemberian informasi penjelasan mengenai sistem pada appraisal.

Memberikan informasi apa saja yang perlu dikuasai oleh seorang juru masak, mengenai penilaian / indikator yang terdapat dalam appraisa dan menggaris bawahi bahwa pentingnya appraisal terhadap kelanjutan kontrak koki berikutnya untuk bekerja di PT Anthony Veder Shipping Management Jakarta. Adanya beberapa alternatif pemecahan masalah yang telah disebutkan, peneliti mencoba mengevaluasi atas alternatif pemecahan masalah tersebut, dengan mempertimbangkan kondisi yang ada di lapangan serta dampak - dampak yang mungkin terjadi dari pemilihan alternatif pemecahan masalah sebagai solusi dari permasalahan yang ada saat ini, namun juga tetap disesuaikan dengan kondisi yang ada pada perusahaan pelayaran Anthony Veder Jakarta, yang mana dapat diuraikan sebagai berikut :

1. Menetapkan IFS Training sebagai standar training yang harus diikuti cook / juru masak kedepannya.

Manajemen Antony Veder bagian Training Department menetapkan setiap juru masak yang baru diterima di Anthony Veder diwajibkan untuk diikutsertakan IFS Training Manila di Filipina. Hal ini berkaitan dengan persiapan juru masak untuk bekerja di atas kapal sesuai dengan ketentuan dan aturan. Yang telah diuraikan pada bab II IFS Training merupakan lembaga / balai pelatihan yang berguna untuk para tenaga kerja di bidang catering department untuk mendapatkan harga / kualitas / dukungan yang baik dalam pemanfaatan bahan makanan (pengolahan). Berkaitan dengan standar, 
IFS Training Manila juga diakui sebagai lembaga yang sudah diakui standarisasi oleh Maritime Labour Convention 2006. Keuntungannya apabila training berhasil menunjukan bahwa adanya perubahan pada appraisal juru masak yang mendeskripsikan kinerja juru masak di atas kapal menjadi lebih baik

2. Merekrut crew yang berkualitas

Membuka penerimaan crew yang sesuai kebutuhan kualifikasi, dengan kata lain membuka kesempatan yang besar bagi para pelaut yang berposisi sebagai juru masak untuk melamar di Anthony Veder Jakarta dan mengikuti test, agar sesuai dengan kualifikasi yang ditetapkan standard recruitment. Karena pembiayaan IFS Training tidak hanya pembiayaan pelatihannya yang tinggi namun pembiayaan keberangkatan tiket dan akomodasi ditanggung langsung oleh Anthony Veder, evaluasi pemecahan masalah dengan merekrut crew yang berkualitas dapat lebih menekan pengurangan biaya perusahaan. Tentunya merekrut crew yang berkualitas juga harus melihat pengalaman dan backgroud juru masak tersebut, seperti dalam merekrut juru masak kita harus melihat dari mana ia mendapat sertifikat cook yang telah diakui kualitasnya. Khususnya di Indonesia terdapat banyak lembaga pelatihan yang cukup baik untuk pelatihan juru masak, namun sampai saat ini belum ada yang diakui oleh Maritime Labour Convention 2006.

\section{Meningkatkan test penyeleksian crew recruitment.}

Test penyeleksian crew recruitment lebih ditingkatkan. Dalam hal ini karyawan recruitment and Selection Department meningkatkan test penyeleksian untuk penerimaan crew baru seperti halnya test tertulis (psikotest, bahasa inggris, pengalaman), test wawancara dengan menggunakan bahasa inggris dikarenakan sebagian besar kapal yang ditangani oleh Anthony Veder Jakarta berlayar ke luar negeri agar nantinya tidak terjadi kesalahan ataupun kecelakaan dalam hal pekerjaan yang dilakukan crew di atas kapal.

4. Meningkatkan kualifikasi crew yang sudah ada.

Strategi ini dapat diterapkan dengan memberikan pelatihan kepada crew sebelum sign on (training pre-joining) dengan mengadakan In House Training sebagai pelatihan kemampuan, diluar kemampuan dasarnya sebagai cook, contohnya kemampuan dalam berbicara dalam bahasa inggris. Dalam hal menciptakan cook yang berkualitas baik cook baru, maupun cook yang sudah dimiliki oleh Anthony Veder Jakarta. Pengertian In House Training ialah pelatihan yang diterapkan oleh Anthony Veder Jakarta dilembaga sendiri yang bertujuan guna meningkatkan kualitas crew yang dimiliki Anthony Veder Rederijzaken B.V.

Pelatihan - pelatihan tersebut diantaranya berupa familiarisasi pekerjaan - pekerjaan yang akan dilakukan oleh cook di atas kapal nanti sesuai dengan jabatan dan tanggung jawab cook. Dengan begitu cook yang telah mengikuti pelatihan tersebut sudah paham akan pekerjaannya di atas kapal kelak. Contohnya seluruh koki harus menyadari pentingnya keselamatan dan keamanan di atas kapal, bidang atau tempat pekerjaannya yang berada di galley / dapur kapal yang rawan akan timbulnya kecelakaan dan bahaya. Hal ini berkaitan dengan keamanan lingkungan di dapur karena, berkaratnya microwave merupakan suatu nearmiss atau potensi dari rusaknya microwave, yang berakibat terbakarnya microwave yang membahayakan keselamatan dan keamanan jiwa seluruh crew di atas kapal.

Pentingnya kesadaran keselamatan dan keamanan koki diatas kapal Anthony Veder meningkatkan kualifikasi crew yang sudah ada dengan memberikan training tambahan seperti Designated Security Duties dan Safety Culture Behaviour Training. Untuk membantu cook yang mengalami masalah dalam bahasa inggris, Anthony Veder akan meningkatkan kualifikasi dengan cara mengadakan English House Training dengan mengundang pengajar bahasa inggris yang akan mengarahkan penggunaan bahasa inggris kepada cook yang bekerja di Anthony Veder. Hal ini bertujuan untuk membantu jenis pekerjaan yang dihadapi cook di atas kapal. Namun akan menjadi kerugian bagi perusahaan Anthony Veder apabila cook tidak dapat mengaplikasikan apa yang diterima pada saat training diwaktu cook bekerja di atas kapal.

5. Pemberian informasi penjelas mengenai sistem pada appraisal.

Memberikan informasi apa saja yang perlu dikuasai oleh seorang juru masak, mengenai penilaian / indikator yang terdapat dalam appraisal. Untuk pemecahan masalah mengenai pemberian informasi bertujuan untuk menyadarkan koki akan pentingnya appraisal terhadap kelanjutan kontraknya dengan perusahaan. Dalam appraisal terdapat 2 indikator yang dinilai oleh master on board yaitu sebagai berikut :

a. Professional Appraisal yaitu indikator yang dinilai berdasarkan profesionalitas seorang juru masak dari mulai dari kemampuan teori dan teknik sampai penggunaan bahasa di atas. Terdapat beberapa poin dalam professional appraisal yaitu :

1) Overall Theorytical / Technical Knowledge yaitu penilaian sejauh mana teknik dan pengetahuan memasak yang dimiliki oleh seorang koki. 
2) Menu Planning yaitu penilaian perencanaan menu setiap harinya yang dilakukan oleh seorang koki.

3) Hygiene yaitu penilaian kebersihan yang dilakukan seorang koki di galley.

4) Safety Awareness yaitu penilaian mengenai kesadaran pentingnya keamanan.

5) Compliance with AV - Policies / Procedure yaitu penilaian pemenuhan kewajiban dari prosedur perusahaan Anthony Veder sebagai koki.

6) Intiative and Decision Making yaitu penilaian mengenai inisiatif dalam menerima saran dan pengambilan keputusan.

7) Ordering and Stock keeping yaitu penilaian mengenai pemesanan dan pengaturan persediaan bahan makanan yang berhubungan dengan provision.

8) English Language yaitu penilaian sejauh mana penguasaan bahasa inggris.

9) Environmental Awareness yaitu penilaian kesadaran pentingnya kesalamatan di atas kapal.

b. Personal Appraisal yaitu penilaian yang berhubungan dengan diri juru masak langsung dengan lingkungan sosial dalam pekerjaannya, sampai ketahanan fisik juru masak dalam waktu bekerja. Terdapat beberapa poin dalam personal appraisal yaitu sebagai berikut :

1) Cooperation with Officer / Ratings On Board yaitu penilaian kerjasama dengan perwira diatas kapal maupun ABK.

2) Personal Appearance / Tidiness yaitu penilaian terhadap penampilan pada saat bekerja atau kerapihan seorang juru masak.

3) Physicall Fitness yaitu penilaian terhadap kesehatan fisik seorang juru masa di atas kapal.

4) Sobriety yaitu penilaian terhadap ketenangan dalam bekerja.

\section{KESIMPULAN}

Berdasarkan penjabaran yang telah peneliti kemukakan pada sebelumnya, dapat disimpulkan bahwa penerapan IFS Training memiliki hubungan dan pengaruh yang signifikan terhadap appraisal koki. Jadi dari hasil analisis statistik diperoleh terdapat pengaruh dan hubungan yang signifikan dari penerapan IFS Training terhadap appraisal koki di PT. Anthony Veder Shipping Management Jakarta setelah mengikuti IFS Training dan kembali bekerja di atas kapal.

Adapun saran yang peneliti berikan sebagai berikut :

1. Untuk Jangka Pendek
Melaksanakan masukan - masukan dari peneliti yang terdapat dievaluasi pemecahan masalah BAB IV seperti :

a) Menetapkan IFS Training sebagai standar training yang harus diikuti cook / juru masak kedepannya .

b) Pemberian informasi penjelas mengenai hal atau poin indikator yang dinilai dalam appraisal.

c) Merekrut cook yang berkualitas

d) Memberikan pelatihan kepada cook sebelum sign on (training pre-joining) dengan mengadakan In House Training.

e) Meningkatkan test penyeleksian crew recruitment.

f) Menjalin hubungan yang erat dengan para awak kapal agar awak kapal, guna terciptanya suasana yang kondusif dan harmonis.

2. Untuk Jangka Panjang

a) Menerapkan ikatan dinas guna mempertahankan jumlah cook yang dimiliki Anthony Veder Ship Management Jakarta.

b) Mendirikan ruang konsultasi bagi para cook ataupun crew lainnya agar dapat berdiskusi langsung dengan pihak perusahaan untuk mengetahui keluhan atau permasalahan yang terjadi di atas kapal.

c) Merekrut pengajar atau senior cook yang mempunyai pengalaman cukup untuk menjadi pengajar Anthony Veder Ship Management Jakarta agar dapat menjadi pengajar dan konsultan di divisi Training Departement.

d) Menambah jumlah sumber daya manusia ( karyawan kantor ) dibidang Training Department / Recruitment and Selection Crew agar dapat membantu tugas dari pada karyawan yang sudah ada, sehingga pembagian kerja menjadi rata dan lebih maksimal.

e) Memberikan kompensasi dan memperhatikan cook selama cook di darat agar cook tersebut tidak pindah ke perusahaan lain dan tetap stand by untuk contract planning selanjutnya.

\section{DAFTAR PUSTAKA}

[1] Arikunto. 2010. Manajemen Penelitian, Jakarta : PT Rineka Cipta

[2] Aritonang, Lerbin R. 2005. Kepuasan Pelanggan. Jakarta : PT Gramedia Pustaka Utama

[3] Tjiptono, Fandy. 2011. Service Management. Yogyakarta : PT Andi Offset

[4] Kotler, Philip dan Kevin L. Keller. 2008. Manajemen Pemasaran. Jakarta : PT Indeks

[5] Marzolina, dan S. R. (2010). Analisis Kepuasan Pelanggan (Penumpang Domestik) Terhadap Kualitas Pelayanan Pada Pt. Angkasa Pura H (Persero) Cabang 
Bandara Sultan Syarif Kasim H Pekanbaru. Jurnal Ekonomi, 18.

[6] Moenir. 2010. Manajemen Pelayanan Umum Di Indonesia. Jakarta : PT Bumi Aksara

[7] Novel1, H., \& , Humala L. Napitupulu, D. (2013). Penilaian Tingkat Kepuasan Pasien Terhadap Pelayanan Jasa Puskesmas Medan Johor Dengan Metode Servperf (Service Performance) Dan Customer Satisfaction Index. E-Jurnal Teknik Industri FT USU

[8] Peraturan Menteri Perhubungan No. 119 Tahun 2015 tentang Standard Pelayanan Penumpang Angkutan Laut.

[9] Sugiyono, P. D. (2013). METODE PENELITIAN BISNIS (Pendekatan Kuantitatif, Kualitatif, dan R\&D). Bandung: Alfabeta.

[10] Supranto, J. 2006. Pengukuran Tingkat Kepuasan Pelanggan untuk Menaikan Pangsa Pasar. Jakarta : PT Rineka Cipta

[11] Tjiptono, Fandy dan Gregious Chandra. 2011. Service, Quality dan Satisfaction. Yogyakarta : PT Andi Offset

[12] Undang - undang RI No. 17 Tahun 2008 tentang Pelayaran. Bandung

[13] Wijaya, Tonny. 2018. Manajemen Kualitas Jasa. Jakarta : PT Indeks 